\title{
Role of Intermediary Cells in Peltodon radicans (Lamiaceae) in the Transfer of Calcium and Formation of Calcium Oxalate Crystals
}

\author{
Elder Antônio Sousa Paiva ${ }^{1 *}$ and Silvia Rodrigues Machado ${ }^{2}$ \\ ${ }^{1}$ Universidade Federal de Minas Gerais; ; Instituto de Ciências Biológicas; Departamento de Botânica, 31270-901; \\ Belo Horizonte - MG - Brazil; epaiva@icb.ufmg.br. ${ }^{2}$ Universidade Estadual Paulista; Instituto de Biociências; \\ Departamento de. Botânica; Caixa Postal:510; 18618-000; Botucatu - SP - Brazil
}

\begin{abstract}
With the objective of studying the connection between calcium oxalate crystals formation and the phloem, fragments of leaves of Peltodon radicans Pohl (Lamiaceae) were fixed and processed, for light and electron-transmission microscopes. It was observed that the crystals occurred in the cells of the bundle sheath, juxtaposed in relation to the phloem. Intermediary cells established a connection between the sieve element and crystal-bearing sheath cells. Calcium was present abundantly in the cytoplasm of sheath cells as calcium oxalate crystals. The presence of calcium was also detected in the intermediary cells, but in the sieve elements it was not detected. There was, therefore, an increasing concentration gradient of calcium in the sieve elements from sheath cells. Thus, we hypothesized that the formation of calcium oxalate crystals regulates calcium levels in the sieve elements.
\end{abstract}

Key words: Calcium oxalate; calcium metabolism; companion cells; crystals; Peltodon radicans; phloem

\section{INTRODUCTION}

Calcium oxalate crystals can occur in all plant tissues (Metcalfe and Chalk, 1983); yet, they appear more frequently and are more abundant adjacent to vascular tissues, especially the phloem. The relation of this preferential distribution of calcium oxalate crystals in proximity to the phloem is found in different plant species (Sunell and Healey, 1985; Zindler-Frank et al., 1988; Zindler-Frank, 1994; Nakata and McConn, 2000). The quantity of crystals encountered in plant tissues depends on, the availability of calcium to the plant (Franceschi and Horner, 1979; ZindlerFrank et al., 2001; Volk et al., 2002). There is a positive correlation between the quantity of calcium supplied to plants and the number of crystals formed (Zindler-Frank et al., 2001). Oxalic acid can have a role in ionic balancing, as it has been observed that increased concentration of $\mathrm{Ca}^{2+}$ results in greater proportions of oxalic acid (Franceschi and Horner, 1980; Keates et al., 2000). For many years oxalic acid has been considered a final product of metabolism, and since this acid is potentially toxic, the function of rendering it inactive has been attributed to calcium oxalate crystals (Kostman et al., 2001). However, recent studies have demonstrated that oxalic acid is synthesized in response to the presence of calcium (Keates et al., 2000), which suggests that biosynthesis of this acid can be induced by the presence of this ion, in the accumulative plants of

\footnotetext{
* Author for correspondence
} 
calcium oxalate. Kostman et al. (2001) demonstrated that the crystalliferous idioblasts in Pistia stratiotes are self-sufficient in the biosynthesis of oxalic acid.

The levels of $\mathrm{Ca}^{2+}$ are low in cytosol, while the vacuole and apoplast shows higher portions of this ion (Gilroy et al., 1993; Bush, 1995). In sieve elements, vacuoles and 'normal' endoplasmic reticulum are absent, hence regulation of $\mathrm{Ca}^{2+}$ activity is thought to be by sequestration within sieve element reticulum or pumping to the apoplast by $\mathrm{Ca}^{2+}$-ATPases (Sjolund and Shih, 1983).

$\mathrm{Ca}^{2+}$-dependent protein kinases indicate a possible role of $\mathrm{Ca}^{2+}$ in signaling within sieve tubes (Nakamura et al., 1995). The presence of $\mathrm{Ca}^{2+}$ channels along the sieve element permits $\mathrm{Ca}^{2+}$ influx from the specialized wall region immediately adjacent to the plasma membrane (Gayle and Franceschi, 2000; Volk and Franceschi, 2000); this increase in cytoplasmatic $\mathrm{Ca}^{2+}$, for example, induces callose synthesis during wounding (Kauss et al., 1991; Gayle and Franceschi, 2000).

Sieve elements metabolism can be compromised by calcium excess (Marschner, 1986); high $\mathrm{Ca}^{2+}$ concentration in these cells also precipitates inorganic phosphate (Gayle and Franceschi, 2000). In the presence of elevated external levels, this ion is actively pumped out of the cytosol (Higinbotham et al., 1967; Raven, 1977; Poovaiah, 1988; Randall, 1992). Thus, it is reasonable to propose that specialized companion cells could be mediating the transfer of calcium from the sieve tube element to the bundle sheath cells, through the symplast, where precipitation occurs, as well as consequent inactivation of this calcium in the form of crystals. According to Volk et al. (2002), to accommodate calcium signaling and mediate the otherwise toxic effects of high cytoplasmic calcium, calcium activity is carefully regulated in tissues and cells by a number of processes.

Recent advances have demonstrated other functions for companion cells, such as supplying energy in the form of ATP to sieve tube elements and participating in the transport of photoassimilates (Taiz and Zeiger, 1998). There are at least three types of companion cells in veins of small-caliber photosynthesizing leaves: ordinary companion cells, transfer cells and intermediary cells (Taiz and Zeiger, 1998). These latter ones are characterized by the presence of numerous plasmodesmata branched into their cell walls, which capacitate them for taking solutes through cytoplasmic connections, and by the presence of fragmented vacuoles (Taiz and Zeiger, 1998).

Calcium oxalate crystals are known to cause irritations in vertebrate herbivores (Franceschi and Horner, 1980). These crystals are associated with the toxic effect of some plants such as Dieffenbachia sp (Gardner, 1994). Other possible functions of the crystals remain somewhat obscure, lacking scientific proof.

The presence of intermediary cells connecting sieve tube elements exclusively with crystalbearing bundle sheath cells in Peltodon radicans leads us to propose a possible role for these cells in the process of transference of calcium from sieve element to the sheath, where formation of calcium oxalate crystals occurs. In this work, evidence of participation of intermediary cells in the formation of calcium oxalate crystals corroborated the results, which attributed to the crystals the role of removal of excess cytosolic calcium.

\section{MATERIAL AND METHODS}

The material consisted of samples of completely expanded leaf blades obtained from Peltodon radicans plants grown in a natural environment. The samples were fixed and processed for study in both light and transmission electron microscope (TEM).

\section{Light microscopy}

For visualization of veins and crystals, samples were fixed in Karnovsky solution (Karnovsky, 1965) for 24 hours, bleached in an aqueous solution of chloral hydrate, washed in distilled water, stained in aqueous solution of $1 \%$ safranine, thus detaching the veins. Then, they were dehydrated in ethanol series and mounted in slides with Canadian balsam (Johansen, 1940).

Fixed samples of materials were embedded in glycol metacrylate historesin. Transverse and paradermal sections $(5 \mu \mathrm{m})$ were obtained by microtome and stained with $0.05 \%, \mathrm{pH} 4.3$, toluidine blue (O'Brien et al. 1964). To identify the chemical nature of the crystals, chloridric acid was utilized with the analysis of solubility (Howart and Horner, 1959). 


\section{Transmission Electron Microscopy}

Samples previously fixed in Karnovsky solution (Karnovsky, 1965) were then fixed in 1\% osmium tetroxide in a $0.1 \mathrm{M}$ phosphate buffer of $\mathrm{pH} 7.2$, dehydrated in an acetone-solution series and embedded in Araldite resin (Roland, 1978). Ultrafine cuts were contrasted with lead citrate and uranyl acetate and observed in a Philips EM 300 electron transmission microscope. Ultracytochemical testes were performed for detection of calcium following Forbes et al., (1977).

\section{RESULTS}

Through the light microscope, the leaf blade of Peltodon radicans presented vascular bundles, as many medium-sized ones as those of small caliber, with the sheath constituted of large parenchyma cells where calcium oxalate crystals were seen.
These crystals (druses) were present exclusively in the sheath cells around the phloem. In bleached leaves, it was possible to observe that the cells containing druses were arranged laterally in relation to the phloem, forming linear sequences extending along all of the dorsal surface of the veins (Fig. 1).

Pyramidal cells with dense cytoplasm arranged laterally with respect to the sieve tube element were observed in transversal cuts of the leaf blade (Fig. 2); in longitudinal cuts these cells were presented as long and accompanied the sieve tube element throughout its range (Fig. 3). The phloem, in smaller-caliber bundles, was constituted by a few sieve tube elements and companion cells of pyramid shape which connected one of the sieve tube elements with a bundle sheath cell (Fig. 2). The pyramidal cells possessed wedge-shaped basal extremities and presented intrusive growth among crystal-bearing sheath cells (Figs. 4 and 5).
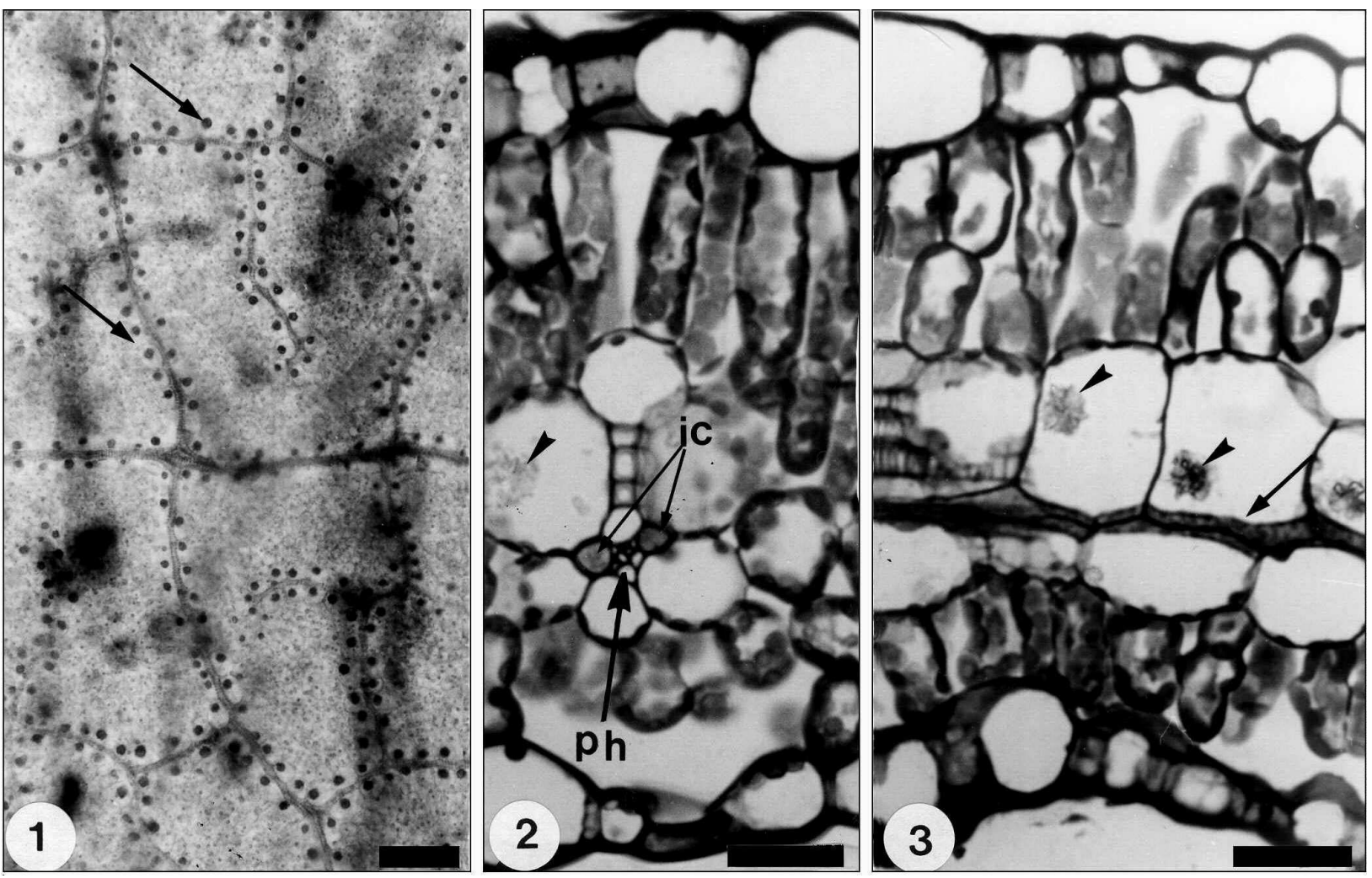

Figures 1 to 3 - Photograph of leaf blade of the $P$. radicans. In 1, frontal view of bleached leaf showing vein distribution and crystals laterally arranged (arrows). In 2, transverse section at middle region of the leaf showing vascular bundle and bundle sheath with druse (arrow head). Intermediary cells (ic) arranged at both sides of phloem (ph). In 3, section of leaf showing vascular bundle at longitudinal view. Druses (arrow head) can be seen at the bundle sheath cells. Notice an intermediary cell (arrow) with dense cytoplasm. (bar $=50 ; 20 ; 20 \mu \mathrm{m}$ respectively) 

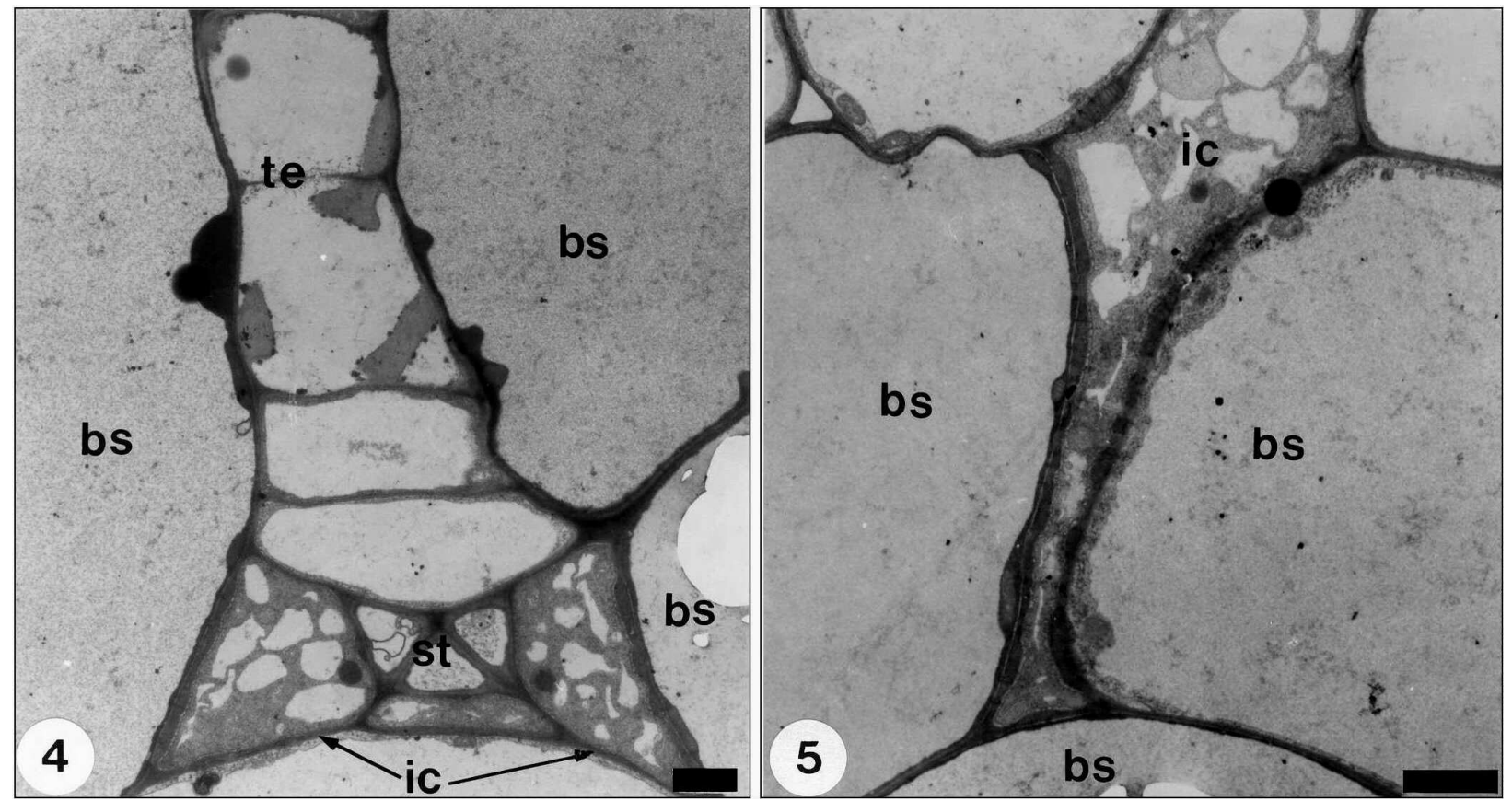

Figures 4 and 5 - TEM photograph of intermediary cell. In 4, vascular bundle showing intermediary cells (ic), tracheal elements (te) and sieve tubes (st). Notice bundle sheath cells (bs) with a large vacuole. In 5, Intermediary (ic) cell with intrusive growth between bundle sheath cells (bs). Notice a dense cytoplasm of the intermediary cell and various vacuoles. (bar $=2 \mu \mathrm{m})$
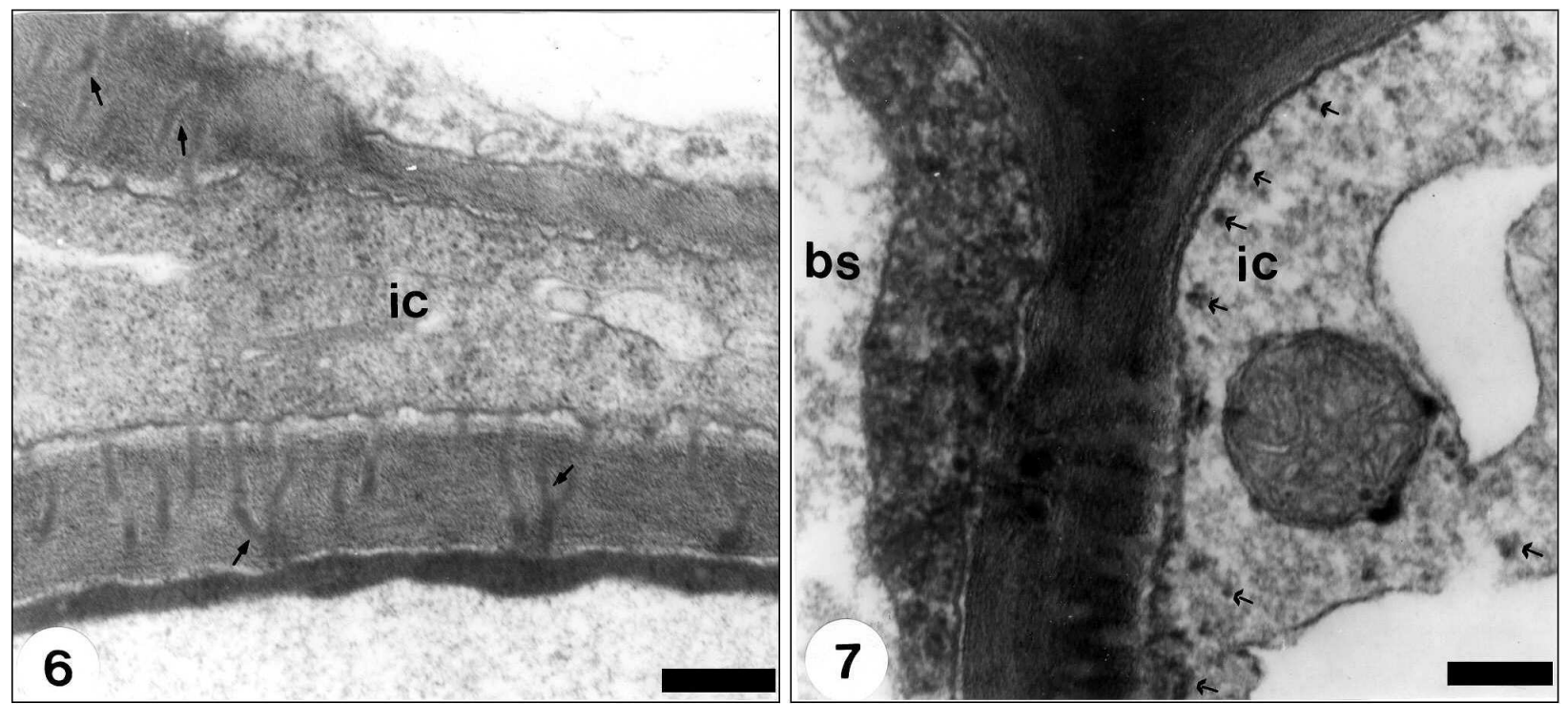

Figures 6 and 7 - TEM photograph of the intermediary cell (ic). In 6, notice a branched plasmodesmata at side of bundle sheath cell (arrows). Fig. 7 - intermediary cell submited a cytochemical test for calcium detection. Notice a dark precipitation (arrows) in cytoplasm of intermediary cell (ic) and bundle sheath cell (bs) with dense precipitation (bar $=0,3$ and $0,2 \mu \mathrm{m}$ respectively). 
In larger-caliber sheaths, the phloem consisted of various sieve tube elements interspersed with companion cells, in addition to the parenchyma cells. Companion cells that were in contact with the bundle sheath had a pyramidal shape and ultrastructural characteristics similar to those observed in sheaths of lesser caliber.

In the companion cells of pyramidal shape, the remarkable characteristics of the walls that bordered the sheath cells were those which had higher electron density and were thicker presenting numerous ramified plasmodesmata (Fig. 6). On the surface of contact with the sieve tube element, the wall was thinner and showed few plasmodesmata. Besides the abundance of plasmodesmata connecting the companion cell with the bundle sheath, the ramifications of these were more developed in the companion cell wall. The cytoplasm of these cells was electron-dense and organelle rich. The nucleus was voluminous, whereas the vacuoles were numerous (Fig.s 4 and 5), small and of variable content.

The ultracytochemical test detected the abundant presence of calcium in the bundle sheath cells around the phloem, visible as electron-dense precipitates (Fig. 7). Calcium was also detected in the intermediary cells, including the ramified plasmodesmata. In the sieve elements, calcium was not detected, whereas there was a welldefined increasing gradient of calcium concentration from the sieve elements to the sheath cells.

\section{DISCUSSION}

The characteristics of companion cells in the phloem of $P$. radicans permit their classification as intermediary cells, which constitute one specialized type of companion cell that acts by mediating the transport between the mesophyll cells and the sieve tube elements, mainly through plasmodesmata (Mauseth, 1988; Taiz and Zeiger, 1998). The fact that numerous symplastic connections occur between the intermediary cells and crystal-bearing sheath cells suggests the participation of the intermediary cells in the process of formation of calcium oxalate crystals by the transfer of sieve tube element calcium to the sheath cells. The intrusive growth of the intermediary cells among the bundle sheath cells promotes expansion in contact surface, increasing the possibility of transport of materials between the phloem and the crystal-bearing sheath cells (see Taiz and Zeiger, 1998).

Our results suggested that the concentration of calcium increased from the sieve tube elements to the bundle sheath, showing that the calcium precipitate in the bundle sheath originated in elements of the phloem. The report on the occurrence of crystals in structures that act as drains, as secretory structures (Schnell et al., 1963; Paiva et al., 2001), was compatible with the idea that the calcium was removed from the phloem. On the other hand, in some situations high calcium concentrations are needed at phloem cells to regulate enzyme activity, example, in the callose synthesis (Kauss et al., 1991; Gayle and Franceschi, 2000). In this case, calcium oxalate crystals at bundle sheath cells can be dissolved and remobilized, thus having different roles in bulk calcium regulation (Volk et al., 2002).

The biosynthesis of oxalic acid seems to act in maintaining the balance of calcium levels in cytosol. In this manner, the occurrence of calcium oxalate crystals may be associated with the process of eliminating excess cytosolic calcium (Kostman et al., 2001). Recently it was demonstrated that the presence of calcium induced the synthesis of oxalic acid, driving the formation of the crystals and thus eliminating the cytosolic calcium (Keates et al., 2000). Some studies suggested that excess apoplastic calcium induced the differentiation of crystal-bearing idioblasts (Borchert, 1986; Volk et al., 2002).

In Phaseolus vulgaris, completely developed leaves presented elevated levels of oxalate in plants cultivated in solution with high calcium levels (Zindler-Frank et al., 2001). This result and also the observation that in Pistia stratiotes the crystal-bearing idioblasts synthesized oxalic acid used in the formation of crystals (Kostman et al., 2001) were compatible with the hypothesis that the formation of crystals had a function of removing excess calcium from cytosol and did not inactivate the oxalic acid.

The hypothesis that the formation of calcium oxalate crystals controls calcium levels in the phloem is reinforced by countless observations of the occurrence of calcium oxalate crystals near the phloem (Paiva, E.A.S. unpublished data), and also by the fact that active calcium extrusion occurs from the sieve tube elements (Raven, 1977). The disposition of the crystals accompanying the veins was also observed by Sunell and Healey (1985); Zindler-Frank et al. (1988) and Nakata and 
McConn (2000). Yet it is important to point out that increases in the amount of calcium oxalate crystals were observed when doses of calcium supplied to the plants were elevated (ZindlerFrank et al., 1988; Zindler-Frank et al., 2001; Volk et al., 2002) which was also compatible with our proposed hypothesis.

Although quantitative tests have not been accomplished, the ultracytochemical test used revealed the occurrence of a gradient of calcium from the sieve tube elements to the crystal-bearing sheath cells, corroborating our hypothesis on the role of intermediary cells in calcium transfer.

\section{RESUMO}

Com o objetivo de estudar a relação entre cristais de oxalato de cálcio e floema, fragmentos de folhas de Peltodon radicans foram fixados e processados, segundo métodos usuais, para estudos ao microscópio de luz e eletrônico de transmissão. Observou-se que os cristais ocorrem nas células da bainha do feixe, lateralmente em relação ao floema. Células intermediárias estabelecem conexão entre elemento crivado e células da bainha, portadoras de cristais, com crescimento intrusivo entre estas. Íons cálcio são abundantes no citoplasma das células da bainha que contém cristais de oxalato de cálcio. Nas células intermediárias a detecção ultra-citoquímica de cálcio também apresentou resultados positivos, enquanto nos elementos crivados a presença deste íon não foi constatada. Há, portanto, um gradiente crescente de concentração de cálcio dos elementos crivados para as células da bainha. Assim, formulamos a hipótese de que a formação de cristais de oxalato de cálcio tem, em $P$. radicans, o objetivo de controlar os níveis de cálcio citossólico nos elementos crivados.

\section{REFERENCES}

Borchert, R. (1986), Calcium acetate induces calcium uptake and formation of calcium-oxalate crystals in isolated leaflets of Gleditsia triacanthos L. Planta, 168, 571-578.

Bush, D. S. (1995), Calcium regulation in plant cells and its role in signaling. Annual Review of Plant Physiology and Mollecular Biology, 46, 95-122.
Forbes, M. S.; Plantholt, B. A. and Speralakis, N. (1977), Cytochemical staining procedures selective for sarcotubular systems of muscle - modifications and applications. Journal of Ultrastructural Research, 60, 306-327.

Franceschi, V. R. and Horner Jr., H. T. (1979), Use of Psychotria punctata callus in study of calcium oxalate crystal idioblast formation. $Z$. Pflanzenphysiology, 92, 61-75.

Franceschi, V. R. and Horner Jr., H.T. (1980), Calcium oxalate crystals in plants. Botanical Review, 46, 361-427.

Gardner, D. G. (1994), Injury to the oral mucous membranes caused by the common houseplant, Dieffenbachia: a review. Oral Surgery Oral Medicine Oral Pathology, 78, 631-633.

Gayle, M. V. and Franceschi, V. R. (2000), Localization of a calcium channel-like protein in the sieve element plasma membrane. Australian Journal of Plant Physiology, 27, 779-786.

Gilroy, S.; Bethke, P. C. and Jones, R. L. (1993), Calcium homeostasis in plants. Journal of Cell Science, 106, 453-462.

Higinbotham, N.; Etherton, B. and Foster, R. J. (1967), Mineral ion contents and cell transmembrane electropotentials of pea and oat seedling tissue. Plant Physiology, 42, 37-46.

Howart, W. O. and Horner, L. G. G. (1959), Practical Botany for the Tropics. Univ. London Press, London

Johansen, D. A. (1940), Plant Microtechnique. New York : McGraw-Hill Book Co.

Karnovsky, M. J. (1965), A formaldehydeglutaraldehyde fixative of high osmolality for use in electron microscopy. Journal of Cell Biology, 27, 137A-138A.

Kauss, H.; Waldmann, T.; Jeblick, W. and Takemoto, J. Y. (1991), The phytotoxin syringomycin elicits Ca 2+-dependent callose synthesis in suspensioncultured cells of Catharanthus roseus. Physiologia Plantarum, 81, 134-138.

Keates, S. E.; Tarlyn, N. M.; Loewus, F. A. and Franceschi, V. R. (2000), L-ascorbic acid and L-galactose are sources of oxalic acid and calcium oxalate in Pistia stratiotes. Phytochemistry, 53, 433-440.

Kostman, T. A.; Tarlyn, N. M.; Loewus, F. A. and Franceschi, V. R. (2001), Biosynthesis of L-ascorbic acid and conversion of carbons 1 and 2 of L-ascorbic acid to oxalic acid occurs within individual calcium oxalate crystal idioblasts. Plant Physiology, 125, 634-640.

Marschner, H. (1986), Mineral Nutrition of Higher Plants. New York : Academic Press.

Mauseth, J. D. (1988), Plant Anatomy. Benjamin Cummings, Menlo Park.

Metcalfe, C. R. and Chalk, L. (1983), Anatomy of the Dicotyledons. Vol. II. New York : Oxford University Press. 
Nakata, P. A. and McConn, M. M. (2000), Isolation of Medicago truncatula mutants defective in calcium oxalate crystal formation. Plant Physiology, 124, 1097-1104.

Nakamura, S.; Hayashi, H.; Mori, S. and Chino, M. (1995), Detection and characterization of protein kinases in rice phloem sap. Plant Cell Physiology, 36, 19-27.

O’Brien, T. P.; Feder, N. and McCully, M. E. (1964), Polychromatic staining of plant cell walls by toluidine blue. Protoplasma, 59, 368-373.

Paiva, E. A. S.; Morais, H. C.; Isaias, R. M. S.; Rocha, D. M. S. and Oliveira, P. E. (2001), Occurence and structure of extrafloral nectaries in Pterodon pubescens Benth. and Pterodon polygalaeflorus Benth. (Fabaceae-Papilionoideae). Pesquisa Agropecuaria Brasileira, 36, 219-224.

Poovaiah, B. W. (1988), Molecular and cellular aspects of calcium action in plants. HortScience, 23, 267-271

Randall, S. K. (1992), Characterization of vacuolar calcium-binding proteins. Plant Physiology, 100, 859-867.

Raven, J. A. (1977), $\mathrm{H}^{+}$and $\mathrm{Ca}^{2+}$ in phloem and symplast: relation of relative immobility of the ions to the cytoplasmic nature of the transport paths. New Phytologist, 79, 465-480.

Roland, A. M. (1978), General preparations and staining of thin sections. In: Hall, J. L. (Ed.). Electron Microscopy and Cytochemistry of Plant Cells. New York : Elsevier. pp. 1-62.

Schnell, R.; Cusset, G. and Quenum, M. (1963), Contribution a l'étude des glandes extra-florales chez quelques groupes de plantes tropicales. Revue Génerale de Botanique, 70, 269-341.

Sjolund, R. D. and Shih, C. Y. (1983), Freeze-fracture analysis of phloem structure in plant tissue cultures. Journal of Ultrastructural Research, 82, 111-121.

Sunell, L. A. and Healey, P. L. (1985), Distribution of calcium oxalate crystal idioblasts in leaves of taro (Colocasia sculenta). American Journal of Botany, 72, 1854-1860.

Taiz, L. and Zeiger, E. (1998), Plant Physiology. Sinauer Associates Inc., Sunderland.
Volk, G. M. and Franceschi, V. R. (2000), Localization of a calcium channel-like protein in the sieve element plasma membrane. Australian Journal of Botany, 27, 779-786.

Volk, G. M.; Lynch-Holm, V. J.; Kostman, T. A.; Goss, L. J. and Franceschi, V. R. (2002), The role of druse and raphide calcium oxalate crystals in tissue calcium regulation in Pistia stratiotes leaves. Plant Biology, 4, 34-45.

Zindler-Frank, E. (1994), Calcium, calcium oxalate crystals, and leaf differentiation in the common bean (Phaseolus vulgaris L.). Botanica Acta, 108, 144-148.

Zindler-Frank, E.; Wichman, E. and Korneli, M. (1988), Cells with crystals of Calcium oxalate in the leaves of Phaseolus vulgaris - a comparison with those in Canavalia ensiformes. Botanica Acta, 101, 246-253.

Zindler-Frank, E.; Honow, R. and Hesse, A. (2001), Calcium and oxalate content of the leaves of Phaseolus vulgaris at different calcium supply in relation to calcium oxalate crystal formation. Journal of Plant Physiology, 158, 139-144.

Received: June 12, 2003; Revised: January 23, 2004; Accepted: May 11, 2004. 